\title{
ACL surgery is not for all patients, nor for all surgeons
}

\author{
Lars Engebretsen
}

Published online: 8 November 2013

(c) Springer-Verlag Berlin Heidelberg 2013

The most typical knee patient seen by me these days is the Norwegian snowboarder, usually in her late teens or early twenties with an anterior cruciate ligament (ACL), meniscal and cartilage injury sustained in New Zealand or Australia this summer training for the Sochi Olympics. The athlete wants to return to the sport as soon as possible-as the games are coming up in February 2014. The athlete is looking for a quick fix. However, my news to them is pretty much not that encouraging. Although I may be able to fix the injury and they might qualify for Sochi, a cruciate ligament injury early in their career in a sport such as alpine skiing events may lead to early OA even with the best treatment and advice. Perhaps if they read the two papers on analysis of the available literature on risk factors and prevention for these injuries in the current KSSTA journal, they may have second thoughts on quick return to the same high activity level [1, 2]. However, if they had read a similar paper based on the AOSSM Hunt Valley initiative published in 2005 on "Understanding and Preventing non-contact ACL injuries" [7], they would have seen that science is indeed taking jumps forward. Yes, we do have more, although still not sufficient, knowledge about the risk factors and prevention of these injuries. Unfortunately, athletes do not seem to spend much time on preventive work, although sound data exist on the benefit of adhering to these programs [3]. Perhaps the coaches should make the players spend some time on this type of

\footnotetext{
L. Engebretsen $(\bowtie)$

Department of Orthopaedic Surgery, Oslo University Hospital, Oslo, Norway

e-mail: lars.engebretsen@medisin.uio.no

L. Engebretsen

Oslo Sports Trauma Research Center, The Norwegian School of Sports Sciences, Oslo, Norway
}

literature instead of Play station? [10]. They should, because an ACL injury will cost from Euro 80,000 and upwards depending on the insurance payment. The player will be out for 6-12 months, and 10 years later, if the meniscus is involved, more than $50 \%$ of them will have grade 1-2 (or more) Kellgren-Lawrence radiographic signs of OA [15]. In Scandinavia, according to the knee ligament registries, approximately 6,000 cruciate ligaments are reconstructed each year, the majority are related to sports injuries and, unfortunately, the majority in the age group 16-22 [5, 6]. The surgical findings are similar between Europe and the USA [5, 6]. The athletes' KOOS score on sport and recreation is approximately 40 points at the time of surgery. Two years after surgery, they may have returned to their sport and have a stable knee, but they do not have a normal knee and their KOOS score in sports is most probably around 70, significantly below the normal population. Granted, these are general ACL patients and athletes spending hours in rehabilitation and training may have a higher score, but this is an early warning sign. Consequently, we need to use the knowledge we have and implement the primary and secondary prevention programs. Perhaps we should not let an athlete return unless they have shown us their willingness and ability to use the preventive programs $[9,14]$.

It remains to be seen whether the development of new surgical procedures (double-bundle or similar) will improve the long-term results we encounter today. In the meantime, there is no doubt that some athletes can cope without surgery [8, 12, 13]. There are some indications related to non-surgical treatment suggesting that very tough rehabilitation may produce copers, even in sports where pivoting occur $[4,11]$. Unlike the surgically treated players, these players know that they have to train extremely hard for their knee to survive and some apparently do [9]. 
You should read the new papers on ACL injury prevention and ask yourself how you can use this knowledge in your athlete population. You need to get the coaching staff and the athletes on your side and you need to start early, with the youngsters. It can be done, but demands teamwork. Although not sufficient, using the available science will reduce the injuries and their ensuing problems.

\section{References}

1. Alentorn-Geli E, Mendiguchia J, Samuelsson K, Musahl V, Karlsson J, Cugat R, Myer GD (2014) Prevention of anterior cruciate ligament injuries in sports. Part I: systematic review of risk factors in male athletes. Knee Surg Sports Traumatol Arthrosc. doi:10.1007/s00167-013-2725-3

2. Alentorn-Geli E, Mendiguchia J, Samuelsson K, Musahl V, Karlsson J, Cugat R, Myer GD (2014) Prevention of non-contact anterior cruciate ligament injuries in sports. Part II: systematic review of the effectiveness of prevention programs in male athletes. Knee Surg Sports Traumatol Arthrosc. doi:10.1007/s00167013-2739-x

3. Engebretsen AH, Myklebust G, Holme I, Engebretsen L (2008) Prevention of injuries among male soccer players. A prospective, randomized intervention study targeting players with previous injuries or reduced function. Am J Sports Med 36(6):1052-1060

4. Gokeler A, Benjaminse A, Hewett TE, Lephart S, Engebretsen L, Ageberg E, Engelhardt M, Arnold MP, Postema K, Otten E, Dijkstra PU (2012) Proprioceptive deficits after ACL injury: are they clinically relevant? Br J Sports Med 46(3):180-192

5. Granan L-P, Bahr R, Steindal K, Furnes O, Engebretsen L (2008) Development of a national cruciate ligament surgery registry: the Norwegian National Knee Ligament Registry. Am J Sports Med 36(2):308-315

6. Granan L-P, Inacio MCS, Maletis GB, Funahashi TT, Engebretsen L (2012) Intraoperative findings and procedures in culturally and geographically different patient and surgeon populations : an anterior cruciate ligament reconstruction registry comparison between Norway and the USA. Acta Ort 83(6): $577-582$
7. Griffin LY, Albohn MJ, Arendt EA, Bahr R, Beynnon BD, Demaio M, Dick RW, Engebretsen L, Garrett WE Jr, Hannafin JA, Hewett TE, Huston LJ, Ireland ML, Johnson RJ, Lephart S, Mandelbaum BR, Mann BJ, Marks PH, Marshall SW, Myklebust G, Noyes FR, Powers C, Shields C Jr, Shultz SJ, Silvers H, Slauterbeck J, Taylor DC, Teitz CC, Wojtys EM, Yu B (2006) Understanding and preventing noncontact anterior cruciate ligament injuries: a review of the hunt vally II meeting, January 2005. Am J Sports Med 34(9):1512-1532

8. Grindem H, Eitzen I, Moksnes H, Snyder-Mackler L, Risberg MA (2012) A pair-matched comparison of return to pivoting sports at 1 year in anterior cruciate ligament-injured patients after a nonoperative versus an operative treatment course. Am J Sports Med 40(11):2509-2516

9. Hurd WJ, Axe MJ, Snyder-Mackler LA (2008) 10-year prospective trial of a patient management algorithm and screening examination for highly active individuals with anterior cruciate ligament injury: part 1, outcomes. Am J Sports Med 36(1):40-47

10. Hägglund M, Waldén M, Magnusson H, Kristenson K, Bengtsson H, Ekstrand J (2013). Injuries affect team performance negatively in professional football: an 11-year follow-up of the UEFA Champions League injury study. Br J Sports Med

11. Logerstedt D, Grindem H, Lynch A, Eitzen I, Engebretsen L, Risberg MA, Axe MJ, Snyder-Mackler L (2012) Single-legged hop tests as predictors of self-reported knee function after anterior cruciate ligament reconstruction: the Delaware-Oslo ACL cohort study. Am J Sports Med 40(10):2348-2356

12. Lynch AD, Logerstedt DS, Grindem H, Eitzen I, Hicks GE, Axe MJ, Engebretsen L, Risberg MA, Snyder-Mackler L (2013) Consensus criteria for defining 'successful outcome' after ACL injury and reconstruction: a Delaware-Oslo ACL cohort investigation. Br J Sports Med. doi:10.1136/bjsports-2013-092299

13. Moksnes H, Engebretsen L, Risberg MA (2012) The current evidence for treatment of anterior cruciate ligament injuries in children is low. A systematic review. J Bone Joint Surg 94-A(12):1112-1119

14. Soligard T, Myklebust G, Steffen K, Holme I, Silvers H, Bizzini M, Junge A, Dvorak J, Bahr R, Andersen TE (2008) Comprehensive warm-up programme to prevent injuries in young female footballers: cluster randomised controlled trial. BMJ 9:337

15. Øiestad BE, Engebretsen L, Storheim K, Risberg MA (2009) Knee osteoarthritis after anterior cruciate ligament injury: a systematic review. Am J Sports Med 37(7):1434-1443 